\title{
AKTIVITAS SITOTOKSIK SENYAWA GOLONGAN FENOLIK DARI EKSTRAK DAUN SIRIH (Piper betle L.)
}

\author{
Abdul Malik,2, Lamek Marpaung ${ }^{2}$, Partomuan Simanjuntak ${ }^{3}$, Pandapotan Nasution ${ }^{4}$ \\ ${ }^{1)}$ Fakultas Keguruan dan Ilmu Pendidikan, Universitas Almuslim, Jl. Almuslim No. 1, \\ Bireuen 24261 Aceh \\ ${ }^{2)}$ Fakultas MIPA, Universitas Sumatera Utara Jl. Bioteknologi No.1, Padang Bulan, \\ Medan Baru, Kota Medan, Sumatera Utara 20155 \\ 3) Puslit Bioteknologi, Lembaga Ilmu Pengetahuan Indonesia (LIPI), Jl. Raya Bogor Km \\ 46 Cibinong 16911 \\ ${ }^{4)}$ Fakultas Farmasi, Universitas Sumatera Utara Jl. Tri Dharma No.5, Padang Bulan, \\ Medan Baru, Kota Medan, Sumatera Utara 20155 \\ Email :malikmnur@gmail.com
}

\begin{abstract}
ABSTRAK
Senyawa golongan fenolik adalah senyawa aktif dari tanaman sirih yang berpotensi digunakan sebagai bahan obat alami. Penelitian ini bertujuan untuk menguji aktivitas sitotoksik senyawa golongan fenolik dari daun sirih (Piper betle L.). Aktivitas sitotoksik diuji dengan mengukur nilai $\mathrm{LC}_{50}$ menggunakan metode Brine Shrimp Lethality Test (BSLT). Ekstraksi dilakukan dengan cara maserasi dengan pelarut metanol $96 \%$. Data yang diperoleh dianalisis dengan Probit Analysis. Hasil penelitian menunjukan bahwa senyawa golongan fenolik dari ekstrak metanol daun sirih memiliki aktifitas sitotoksik yang dengan nilai $\mathrm{LC}_{50}=3,92 \mathrm{ppm}$ dengan standart error $0,42 \mathrm{ppm}$.
\end{abstract}

Kata kunci: Senyawa fenolik, sirih, Piper betle, sitotoksik

\section{THE CYTOTOXIC ACTIVITY OF PHENOLIC COMPOUNDS GROUP FROM THE BETEL LEAF EXTRACT (Piper betle L.)}

\begin{abstract}
The cytotoxic activity test of the phenolic compounds group from the leaves of Piper betle L. have been performed using the Brine Shrimp Lethality Test (BSLT) method. Maceration methods using $96 \%$ methanol was used to extract the phenolic compounds from the betel leaves. The obtained data ware analyzed using Probit Analysis method. The present results showed that the phenolic compound of the betel leaves have high cytotoxic activity with a value of $\mathrm{LC}_{50}=3.92 \mathrm{ppm}$ at standard error of $0.42 \mathrm{ppm}$.
\end{abstract}

Keywords: Betel, Piper betle, cytotoxic activity, phenolic compounds 


\section{PENDAHULUAN}

Tumbuhan sirih sudah sangat populer di kalangan masyarakat Asia seperti Indonesia, Malaysia, India, Cina, dan Nepal. Sejak beberapa abad yang lalu sirih telah digunakan sebagai obat oleh bangsa Cina dan India (Pradhan et al., 2013). Daun sirih hijau (Piper betle L.) biasa dikonsumsi sehari-hari oleh sebagian masyarakat Asia (Dinesh et al., 2016). Secara tradisional, daun sirih hijau dipercaya dapat digunakan untuk mengatasi bau mulut dan bau badan, sembelit, sakit kepala, gangguan saraf, gatal-gatal, kadas, bisul, rematik, luka lecet, dan lain-lain (Guha, 2006).

Penelitian dengan subjek tumbuhan sirih sudah banyak dilakukan diantaranya untuk mempelajari potensi antioksidan ekstrak daun sirih, sifat sitotoksik ekstrak etanol daun sirih merah, dan bioaktivitas antidiabetes ekstrak etanol dan ekstrak air daun sirih (Makpol et al., 2013, Emrizal et al., 2014, dan Arambewela et al., 2005). Dari berbagai hasil penelitian daun sirih diketahui secara luas memiliki sifat-sifat antifungi, antioksidan, antiplatelet, antipiretik, antiinflamasi, antitrombotik, dan sebagai depresan (Sripradha, 2014).

Potensi daun sirih sebagai obat tradisional dan relevansinya sebagai obat alternatif untuk beragam penyakit tidak lepas dari senyawa aktif yang terkandung didalamnya. Pengembangan obat tradisional berbahan dasar seperi sirih dapat ditingkatkan dengan mengetahui senyawa aktif yang terkandung dalam tanaman tersebut berikut struktur kimianya (Malik, 2016). Sejauh ini, belum ada laporan penelitian mengenai penggunaan tanaman sirih sebagai bahan obat tradisional yang melibatkan aspek-aspek kimiawi maupun biologi dari senyawa golongan fenolik yang diperoleh dari daun sirih. Oleh karena itu, penelitian ini bertujuan untuk mempelajari sifat-sifat sitotoksik kumpulan senyawa fenolik yang terdapat dalam daun sirih, khususnya sirih hijau yang biasa dikonsumsi oleh masyarakat Indonesia.

\section{METODE PENELITIAN \\ Bahan}

Material sampel daun sirih diambil dari ladang sirih Desa Matangdrien, Tanah Jambo Aye, Aceh Utara, Aceh. Sementara bahan kimia yang digunakan meliputi berbagai pelarut organik seperti metanol, $n$-heksana, etil asetat, $\mathrm{FeCl}_{3}$, aquades, dan serbuk silika.

\section{Alat \\ Alat-alat yang digunakan dalam penelitian ini adalah peralatan reflux, rotary evaporator (Buchi R-114), penangas air, kolom kromatografi, corong pisah, gelas kimia, erlenmeyer (Pyrex), dan pelat KLT.}

\section{Cara Kerja \\ Preparasi Sampel}

Sebanyak $6 \mathrm{~kg}$ daun sirih dicuci dan dikeringkan dengan cara diangin-anginkan kemudian dihaluskan sampai menjadi serbuk menggunakan penggiling daun. Serbuk daun sirih selanjutnya diekstraksi dengan cara maserasi.

\section{Maserasi Serbuk Daun Sirih}

Serbuk daun sirih ditimbang sebanyak $1 \mathrm{~kg}$ kemudian direndam dalam wadah kaca dengan $3000 \mathrm{~mL}$ metanol 96\% pada suhu kamar selama 24 jam. Hasil rendaman disaring, filtratnya, ampasnya diekstraksi lagi dengan volume yang sama, ekstraksi dilakukan berulang sampai pelarut jernih. Filtrat dikumpulkan dan dipekatkan dengan rotary evaporator.

\section{Uji Fitokimia Daun Sirih}

Sebelum dilakukan proses pemekatan, sejumLah filtrat hasil maserasi diuji kandungan senyawa fitokimianya menggunakan beberapa pereaksi yaitu pereaksi $\mathrm{FeCl}_{3}$, pereaksi Meyer, pereaksi 
Bouchardat, pereaksi Dragendorf/ Wagner dan aquades, dengan cara sebagai berikut:

1. Sebanyak $10 \mathrm{~mL}$ ekstrak metanol daun sirih $10 \mathrm{~mL}$ ditambah 3 tetes larutan $\mathrm{FeCl}_{3} \quad 5 \%$, diamati perubahan yang terjadi.

2. Cara kerja di atas diulang secara berturut turut dengan menggunakan pereaksi Meyer, Bouchardat, dan Dragendorf/Wagner.

3. Larutan ekstrak metanol daun sirih $10 \mathrm{~mL}$ ditambahkan dengan $2 \mathrm{~mL}$ aquades dikocok beberapa saat. Lalu diamati ada tidaknya pembentukan buih.

\section{Isolasi Senyawa Fenolik}

Isolasi senyawa fenolik dilakukan berdasarkan prosedur-prosedur yang pernah dilakukan sebelumnya (Erwin et al., 2013, Riris et al., 2014) dengan sedikit modifikasi. Ekstrak metanol daun sirih hasil pemekatan sebelumnya dilarutkan dengan aquadest, lalu disaring dan filtrat dipartisi dengan etil asetat (1:1) secara bertahap sampai fraksi etil asetat menunjukkan hasil negatif uji fenolik, yaitu ketika larutan uji tidak berubah menjadi hijau kehitaman ketika ditetesi dengan pereaksi $\mathrm{FeCl}_{3}$.

Fraksi etil asetat selanjutnya dipekatkan dan dilarutkan kembali dengan metanol kemudian dipartisi dengan $n$ heksana untuk memisahkan senyawa nonpolar. Fraksi metanol yang diperoleh dipekatkan untuk memperoleh fenolik total.

\section{Uji Aktifitas Sitotoksik Senyawa Fenolik}

Uji toksisitas dilakukan dengan menggunakan metode Brine Shrimp Lethality Technique (BSLT). Sampel senyawa fenolik yang akan diuji $100 \mathrm{mg}$ ditambah DMSO 3 tetes lalu diencerkan dengan air laut sampai100 $\mathrm{mL}$ untuk mendapatkan larutan sampel $1000 \mathrm{bpj}$, selanjutnya dicairkan secara seri $(100,10$ bpj) dengan air laut.

Larva udang A. salina Leach 10 nauplii yang berumur 48 jam ditambahkan kedalam setiap set tabung uji yang mengandung sampel senyawa fenolik. Larutan yang mengandungi $50 \mu \mathrm{l}$ DMSO dalam air laut digunakan sebagai kontrol. Dua puluh empat jam kemudian, jumLah nauplii yang bertahan hidup dihitung dan jumLah yang mati dicatat. Percobaan dilakukan pada berbagai variasi konsentrasi larutan ekstrak dan dilakukan 3 kali pengulangan (triplo) untuk tiap konsentrasi. Lethal Concentration 50\% (nilai LC $\mathrm{L}_{50}$ ) dihitung dengan Probit Analysis (Vincent, 2008).

\section{HASIL DAN PEMBAHASAN \\ Skrining Fitokimia Daun Sirih}

Proses skrining memberikan hasil positif dengan pereaksi $\mathrm{FeCl}_{3}$ (Tabel 1) yang menunjukkan bahwa sampel daun sirih memiliki kandungan senyawa fenolik yang tinggi.

Tabel 1. Hasil Skrining Ekstrak Metanol Daun Sirih

\begin{tabular}{|c|c|c|c|}
\hline No. & Pereaksi & Hasil & Keterangan \\
\hline 1. & $\begin{array}{l}\mathrm{FeCl}_{3} \text { 1\% (uji } \\
\text { fenolik) }\end{array}$ & $\begin{array}{l}\text { Larutan jadi } \\
\text { hitam }\end{array}$ & $\begin{array}{l}\text { Positif } \\
\text { fenolik }\end{array}$ \\
\hline 2. & $\begin{array}{l}\text { Meyer } \\
\text { alkaloid) }\end{array}$ & $\begin{array}{l}\text { Tidak ada } \\
\text { perubahan }\end{array}$ & $\begin{array}{l}\text { Negatif } \\
\text { alkaloid }\end{array}$ \\
\hline 3. & $\begin{array}{l}\text { Dragendorf } \\
\text { (uji alkaloid) }\end{array}$ & $\begin{array}{l}\text { Tidak } \\
\text { mengendap }\end{array}$ & $\begin{array}{l}\text { Negatif } \\
\text { alkaloid }\end{array}$ \\
\hline 4. & $\begin{array}{l}\text { Bouchardat } \\
\text { (uji alkaloid) }\end{array}$ & $\begin{array}{l}\text { Tidak } \\
\text { mengendap }\end{array}$ & $\begin{array}{l}\text { Negatif } \\
\text { alkaloid }\end{array}$ \\
\hline 5. & $\begin{array}{l}\text { Aquadest (uji } \\
\text { saponin) }\end{array}$ & $\begin{array}{l}\text { Tidak } \\
\text { berbuih }\end{array}$ & $\begin{array}{l}\text { Negatif } \\
\text { saponin }\end{array}$ \\
\hline
\end{tabular}

Senyawa fenolik memiliki gugusgugus fungsi $-\mathrm{OH}$ yang berinteraksi dengan ion besi $\mathrm{Fe}^{3+}$ dari $\mathrm{FeCl}_{3}$ menghasilkan suatu senyawa kompleks yang memberikan warna hijau kehitaman dari larutan (Artini et al., 2013). Daun sirih hijau memiliki kandungan senyawa alkaloid yang rendah. Hal ini ditunjukkan oleh hasil negatif dari uji menggunakan 
reagen Meyer, Dragendrorf, maupun reagen Bouchardat.

Berbeda dengan sirih merah yang memiliki kadar alkaloid yang tinggi (Emrizal et al., 2014), daun sirih hijau justru memperınatkan renaannya kandungan senyawa tersebut. Bahkan, dalam hal ini tidak terdeteksi dengan uji-uji yang telah dilakukan dengan menggunakan pereaksi Meyer, Dragendrorf, maupun reagen Bouchardat. Senyawa yang aktif secara biologi dalam sirih, kadarnya sangat tergantung pada varietas, musim, dan cuaca di daerah tumbuhnya (Sripradha, 2014) Hasil uji negatif dengan aquades menunjukkan bahwa daun sirih memiliki kandungan saponin vang iuga rendah.

\section{Aktifitas Sitotoksik Senyawa Fenolik}

Total senyawa fenolik yang diperoleh dari serangkaian proses isolasi sebanyak 5,36 g $(0,089 \%)$ dalam bentuk liquid berwarna coklat tua. Uji aktifitas sitotoksik senvawa fenolik dilakukan dengan menggunakan metode BSLT, sebuah metode yang mudah dan murah (Meyer et al., 1982).

Dengan menggunakan analisis probit, data hasil uji aktifitas sitotoksik senyawa fenolik dalam laporan ini (Tabel 2) terlebih dahulu dikonversikan kedalam variabel $\mathrm{X}$ dan $\mathrm{Y}$ (Tabel 3) dimana, $\mathrm{X}$ adalah log konsentrasi dan $\mathrm{Y}$ adalah probit mortalitas larva berdasarkan Tabel Nilai Probit (Finney, 1952). Selanjutnya, data dianalisis dengan menggunakan software MS. Excel sehingga diperoleh hubungan antar variabel memenuhi persamaan

$y=1,175 X+4,303$

Grafik hubungan antar variabel

(Gambar 1), dengan koefisien determinasi sebesar 0.870 menunjukkan hubungan yang cukup baik dimana, faktor konsentrasi sampel mempengaruhi mortalitas larva dengan intensitas $87 \%$ dan hanya terdapat $13 \%$ pengaruh dari faktor selainnya.
Tabel 2. Data Mortalitas Dari 10 nauplii Pada Setiap Replikasi

\begin{tabular}{lllll}
\hline \multirow{2}{*}{ Renlikasi } & & \multicolumn{3}{c}{ Mortalitas } \\
& Kontrol & $\begin{array}{l}\mathbf{1 0} \\
\text { bpj }\end{array}$ & $\begin{array}{l}\mathbf{1 0 n} \\
\text { bpj }\end{array}$ & $\begin{array}{c}\mathbf{1 0 n} \\
\text { bpj }\end{array}$ \\
\hline 1 & 1 & 8 & 8 & 10 \\
2 & 1 & 8 & 9 & 10 \\
3 & 0 & 7 & 9 & 10 \\
Total & 2 & 23 & 26 & 30 \\
Proporsi & 6,67 & 76,67 & 86,67 & 100 \\
$(\%)$ & & & & \\
\cline { 2 - 5 }
\end{tabular}

Tabel 3. Konversi Data Berdasarkan Probit

\begin{tabular}{|c|c|c|c|c|c|}
\hline No. & $\mathrm{N}$ & $X$ & $\mathrm{Y}$ & $y$ & $\mathrm{~W}^{*}$ \\
\hline 1. & 30 & 1 & 5,740 & 5,478 & 0,581 \\
\hline 2. & 30 & 2 & 6,130 & 6,653 & 0,223 \\
\hline 3. & 30 & 3 & 8,090 & 7,828 & 0,125 \\
\hline $\begin{array}{l}\text { JumL } \\
\text { h }\end{array}$ & & & & & \\
\hline
\end{tabular}

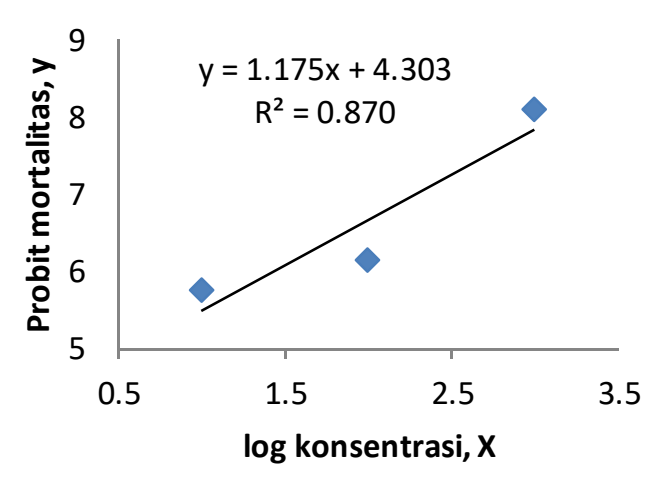

Gambar 1. Regresi Linear Antara Log Konsentrasi Dengan Nilai Probit Mortalitas

Hasil perhitungan Lethal Consentration dari senyawa fenolik hasil ektraksi menunjukkan nilai $\mathrm{LC}_{50}$ sebesar $3.92 \pm 0.42$ bpj. Hasil ini mengindikasikan bahwa aktifitas sitotoksik senyawa fenolik terhadap larva udang sangat tinggi berdasarkan pada literatur (Meyer et al., 1982), yang mengklasifikasi ekstrak dan senyawa murni sebagai beracun (nilai $\mathrm{LC}_{50}<1000 \mu \mathrm{g} / \mathrm{mL}$ ) dan tidak beracun (nilai $L_{50}>1000 \mu \mathrm{g} / \mathrm{mL}$ ). Namun masih 
kurang toksik jika dibandingkan dengan ekstrak metanol kulit biji mahkota dewa (Phaleria macrocarpa) dengan nilai $\mathrm{LC}_{50}$ mencapai $0.16 \mu \mathrm{g} / \mathrm{mL}$ (Lisdawatiet al., 2006).

\section{SIMPULAN DAN SARAN}

Senyawa fenolik dari sumber daun sirih hijau memiliki aktifitas sitotoksik yang tinggi dengan nilai $\mathrm{LC}_{50}$ sebesar 3,92 dan standard error 0,42. Nilai ini dapat dijadikan acuan untuk menjadikan kumpulan senyawa fenolik dari daun sirih sebagai alternatif obat herbal dengan terlebih dahulu diuji bioaktivitasnya seperti antimikroba, antioksidan, antikanker, antidiabetes, dan lain-lain. Perlu dilakukan kajian lebih lanjut untuk mengetahui struktur senyawa-senyawa fenolik tanaman sirih serta mempelajari lebih lanjut aktifitas biologisnya.

\section{DAFTAR PUSTAKA}

Tulisan ini merupakan sebuah laporan awal dari penelitian yang dibuat untuk melengkapkan disertasi yang sedang dipersiapkan. Penulis menyampaikan terimakasih kepada Kemenristekdikti yang telah menyediakan beasiswa, BPP-DN Universitas Almuslim Bireuen yang telah memfasilitasi studi program S3 dan Fakultas MIPA USU Medan sebagai tempat melanjutkan studi.

\section{DAFTAR PUSTAKA}

Arambewela, L.S.R., L.D.A.M.

Arawwawala, W.D. Ratnasooriya. 2005. Antidiabetic activities of aqueous and ethanolic extracts of Piper betle leaves in rats. Journal of Ethnopharmacology. 102: 239-245. Artini, P.E.U.D., W. Astuti, N.K.

Warditiani. 2013. Uji Fitokimia Ekstrak Etil Asetat Rimpang Bangle (Zingiber purpureum Roxb.). Jurnal Farmasi Udayana. 2(4): 1-7.
Dines , M.D., Athira, P.S., Ajma, N., Abisha, N. dan C. Ashitha. 2016. A short review on piper betel (betel leafs). Global Journal of Advanced Research. 3(5): 341-344.

Emrizal, E., A. Fernando, R. Yuliandari, K. Rullah, N.R. Indrayani, A. Susanty, R. Yerti, F. Ahmad, H.M. Sirat, dan D. Arbain. 2014. Cytotoxic activities of fractions and two isolated compounds from Sirih Merah (Piper crocatum Ruiz \& Pav.). Procedia Chemistry. 13: 7984.

Erwin, E., D. Fitria, S. Sari, C. Saleh. 2013. Uji toksisitas dan penentuan aktivitas antioksidan dengan metode DPPH dari metabolit sekunder fraksi $n$-heksan, etil asetat dan metanol-air daun sisik naga (Drymoglossum piloselloides [Linn.] Pr.). Prosiding Seminar Nasional Kimia. Hal: 52-58.

Finney, D.J. dan W.L. Stevens. 1948. A table for the calculation of working probits and weights in probit analysis. Biometrika. 35 (1): 191201.

Finney, D.J., Ed. 1952. Probit Analysis. Cambridge University Press. England.

Guha, P. 2006. Betel leaf: the neglected green gold of India. J. Hum. Ecol. 19 (2): 87-93.

Lisdawati, V., S. Wiryowidagdo, L.B.S. Kardono. 2006. Brine Shrimp Lethality Test (BSLT) dari berbagai fraksi ekstrak daging buah dan kulit biji mahkota dewa (Phaleria Macrocarpa). Bul. Penel. Kesehatan. 34(3): 111-118. Makpol, S., T. W. Yeoh, F.A.C Ruslam, K.T. Arifin, Y.A.M Yusof. 2013. Comparative effect of Piper betle, Chlorella vulgaris and tocotrienolrich fraction on antioxidant enzymes activity in cellular ageing of human diploid fibroblasts. $B M C$ 
Complementary and Alternative

Medicine. 13: 210.

Malik, A. 2016. Aktivitas antidiabetes ekstrak etanol daun sirih dan isolasi senyawa bioaktif. Prosiding Seminar Nasional Kimia dan Pendidikan Kimia 2016. Hal: 1-6. Meyer, B.N., N.R. Ferrigni, J.E. Putnam, L.B. Jacobsen, D.E Nichols dan J.L. McLaughlin. 1982. Brine shrimp: a convenient general bioassay for active plant constituents. Planta Med. 45: 31-4.

Pradhan, D., K.A. Suri, D.K. Pradhan dan P. Biswasroy. 2013. Golden heart of the nature: Piper betle Linn. Journal of Pharmacognosy and
Phytochemistry. 1(6) Issue: 147-

167.

Riris, I.D., T. Barus, P. Simanjuntak dan

B. Wirjosentono. 2014. Isolation and structure elucidation of bioactive compounds chemical as inhibitors of the enzyme $\alpha$ glucosidase raru bark ethanol extract (Vatica pauciflora Blume). International Journal of Chemistry. 6(2): 15-21.

Sripradha, S. 2014. Betel leaf - The green gold. J. Pharm. Sci. \& Rev. 6 (1): 36-37.

Vincent, K. 2008. Probit Analysis. http://www.sfsu.edu/efc/classes/biol 710/probit/ProbitAnalysis.pdf. Diakses pada 13-03-2017. 